\title{
How Do Immigrants Respond to Discrimination? The Case of Germans in the US During World War I VASILIKI FOUKA Stanford University
}

\begin{abstract}
$T$ study the effect of taste-based discrimination on the assimilation decisions of immigrant minorities. Do discriminated minority groups increase their assimilation efforts in order to avoid discrimination and public harassment or do they become alienated and retreat in their own communities? I exploit an exogenous shock to native attitudes, anti-Germanism in the United States during World War I, to empirically identify the reactions of German immigrants to increased native hostility. I use two measures of assimilation efforts: naming patterns and petitions for naturalization. In the face of increased discrimination, Germans increase their assimilation investments by Americanizing their own and their children's names and filing more petitions for US citizenship. These responses are stronger in states that registered higher levels of anti-German hostility, as measured by voting patterns and incidents of violence against Germans.
\end{abstract}

D iscrimination on the basis of ethnicity and religion has been identified as one of the key impediments to the economic and social integration of immigrants. A large number of studies document this phenomenon, but significantly less research has been devoted to understanding how immigrants react to discrimination and how they modify their efforts to assimilate. This is a question of both theoretical interest and policy relevance, with an answer that is not clear a priori: some members of discriminated minority groups make costly investments in assimilation, but for others, low returns to this investment can discourage assimilation and feed back into the majority further discriminating against them. In some extreme cases, minorities may even react by radicalizing and undertaking explicit oppositional actions to reaffirm their identity (Bisin et al. 2011).

Recent research in political science and related disciplines has extensively analyzed drivers of native attitudes toward immigrants (Brader, Valentino, and Suhay 2008; Dinas et al. 2017; Hainmueller and Hopkins 2014; Sides and Citrin 2007; Sniderman, Hagendoorn, and Prior 2004; Steinmayr 2018). Less is known about how such attitudes affect immigrants' political behavior. Studies on the effects of perceptions of discrimination have shown that both alienation and an increase in political engagement are possible outcomes of discriminatory behavior (DeSipio 2002; Oskooii 2018; Schildkraut 2005; Sidanius et al. 1997; Uhlaner 1991). Yet most of these studies rely on correlational evidence that ties minorities' self-reported attitudes and

\footnotetext{
Vasiliki Fouka (D), Assistant Professor, Department of Political Science, Stanford University, vfouka@stanford.edu.

I thank Elias Dinas, Steve Haber, David Laitin, Agustina Paglayan, Ken Scheve, Alain Schlaepfer, Tetyana Surovtseva, Hans-Joachim Voth, Gavin Wright and seminar participants at Stanford, Berkeley, the Ohio State University, the Berkeley CPD Faculty/Graduate Working Group and the 2017 ASREC conference in Boston for helpful comments and suggestions. Replication files are available at the American Political Science Review Dataverse: https://doi.org/ 10.7910/DVN/DHZBAB.
}

Received: June 27, 2017; revised: September 6, 2018; accepted: January 7, 2019. First published online: March 4, 2019. behaviors to their self-reported experiences of discrimination in surveys.

Whether in surveys or in observational contexts, interpreting such correlations causally is challenging. It is empirically hard to disentangle the reactions of minorities from the effects of discrimination, because discrimination is usually endogenous to a minority group's characteristics and pre-existing assimilation trends. Less-integrated minority members are more (or less) likely to be discriminated and to report higher (or lower) perceptions of discrimination. Their attitudes and behaviors may be as much a cause of discrimination as an effect.

To circumvent this problem, studies have relied on laboratory manipulations in perceptions of discrimination to gauge effects on minority attitudes and behavior (Kuo, Malhotra, and Mo 2017). Only a few studies exploit exogenous shocks to actual discrimination, most notably the case of 9/11 (Dávila and Mora 2005; Gould and Klor 2016; Neeraj, Kaestner, and Reimers 2005). Even then, observed effects on socioeconomic indicators of immigrants are equilibrium outcomes, partly owed to changes in minority behavior in response to discrimination and partly due to the actions of natives. If immigrant minorities are observed to participate less in the labor market or intermarry less with natives, this may be because of obstacles raised by the natives and despite immigrants' own best efforts to integrate.

This paper deals with these empirical challenges by using an exogenous shock to native attitudes to identify the causal effect of societal discrimination on the integration decisions of immigrant minorities. I focus on the case study of German Americans in the early twentieth century US. Germans constituted a large and fairly well-integrated group of immigrants until the outbreak of World War I, when they became the target of nationalist sentiment and widespread discrimination and harassment. I examine the effect of the war on the assimilation patterns of German Americans using three measures of assimilation effort: choices of first names for children, petitions for naturalization, and name changes among Germans who petition for citizenship. Unlike other measures of assimilation, such as wages or intermarriage patterns, these outcomes reflect the 
decisions of immigrants and not the constraints of the native environment. I compare Germans to other nationalities before and after WWI in a difference-indifferences framework and find that Germans respond to increasing suspicion on the part of the native population by intensifying their assimilation efforts. The first names of children born during and after the war are less distinctively German than those of earlier cohorts, and the number of petitions for naturalization filed by Germans increases after 1917. These effects are large. Among 16 ethnic groups, ranked from least to most distinctive in terms of first names, Germans moved from ninth place before the war to second in the post-war period. Naturalization petitions among Germans more than doubled compared to the pre-war average. This pattern also holds within households that had children before and after the war and is thus not solely attributable to the least assimilated Germans leaving the country in response to the war. Furthermore, in naturalization documents filed during and after the war, German immigrants are more likely to Americanize their first names.

I construct two measures of the intensity of antiGerman sentiment at the state level. The first one is based on patterns of support for Woodrow Wilson in the presidential election of 1916 . Wilson not only openly supported the Allied cause, but was also a vocal enemy of "hyphenated Americans" and to a large extent fomented anti-German propaganda and contributed to the persecution of German Americans suspected of disloyalty. Additionally, I compile a list of incidents of anti-German hostility reported in the press during the period 1917-18. In states where democratic vote shares in the 1916 presidential election increased relative to previous elections, and where harassment incidents were relatively more frequent, names of German children become more American-sounding at the start of WWI.

This paper makes four main contributions. First, unlike correlational studies, it uses an exogenous change in hostile native attitudes that is unrelated to immigrant outcomes and previous assimilation patterns to identify minority responses. Second, it introduces a distinction between observed assimilation outcomes and minority assimilation decisions. Political representation, labor market outcomes and intermarriage decisions are all determined in equilibrium by joint decisions of immigrants and natives. I focus instead on measures of assimilation that are purely under the control of the discriminated group and thus isolate immigrant responses from the constraints that natives impose on immigrants in social and economic settings.

Third, the paper contributes to a growing literature in political science on the drivers and effects of naturalization. Naturalization is a pathway to formal political participation and has additionally been shown to increase the social and political integration of immigrants (Hainmueller, Hangartner, and Pietrantuono 2015, 2017). Furthermore, studies show that immigrants who naturalize in a politically charged environment are those who feel strongly about the political issues at hand and seek enfranchisement as an act of political expression (Mohamed 2017; Pantoja, Ramirez, and
Segura 2001). This paper shows in a causally identified way how discrimination can impact the decision to naturalize. It also highlights an aspect of this decision that is often ignored by the literature: beyond the instrumental role of naturalization for formal political participation, the decision itself has a signaling value and can be used as a strategy of observable assimilation by minorities facing hostility.

Finally, this study adds to a large literature in political science on the formation of ethnic and national identity. Constructivist views of ethnicity view it as "fluid and endogenous to a set of social, economic and political processes" (Chandra 2001). Studies have examined different determinants of ethnic identity, such as electoral institutions (Laitin 1986; Posner 2005) or political elites (Fearon and Laitin 1996). Closely related to approaches that emphasize the rational nature of identity choice (Laitin 1998, 1995), this study contributes to this literature by causally identifying the impact of native attitudes as an additional "shifter" of costs and benefits considered by minorities when they make their assimilation decisions.

The rest of the paper proceeds as follows: I first review literature that has connected discrimination to the assimilation decisions of immigrants. I then discuss the historical background of German immigration in the United States and anti-German sentiment during World War I. Next, I outline the data and empirical strategy, and present the main results on the effect of the war on German assimilation. I conclude by discussing the implications of the findings for theories of assimilation and discrimination.

\section{DISCRIMINATION AND ASSIMILATION}

Discrimination against immigrants has been documented by a number of studies. There is evidence that immigrants are discriminated against in hiring decisions (Duguet et al. 2010; Oreopoulos 2011), by party gatekeepers who influence access to political representation (Dancygier et al. 2015), and during the process of application for citizenship (Hainmueller and Hangartner 2013). The idea that immigrants may respond to such behavior by investing less in assimilation and retreating into their own ethnic enclaves has found some empirical support. Adida, Laitin, and Valfort (2014) identify a "discriminatory equilibrium" in France, whereby Muslims react to discrimination with alienation and mistrust toward natives. Schildkraut (2005) documents a correlation between Latinos' perceptions of discrimination and low political participation. A few studies find an association between native hostility and radicalization among Muslims in the US and Europe (Lyons-Padilla et al. 2015; Mitts 2018). Gould and Klor (2016) find that the increase in hate crimes after 9/11 reduced the integration of Muslims in the US along dimensions such as intermarriage, female labor force participation, and English language skills. The latter is the only study that exploits a temporally exogenous increase in discrimination to investigate minority assimilation patterns. 
At the same time, research indicates that minorities do exercise their option of assimilating to avoid discrimination. "Passing" for white was a strategy for improving one's economic situation that was sometimes employed among blacks in the US during the Jim Crow era (Mill and Stein 2016; Nix and Qian 2015; Saperstein and Penner 2012). Immigrants during the era of mass migration Americanized their names and in so doing achieved better labor market outcomes, a fact that implies that there was a penalty on foreign-sounding names (Biavaschi, Giulietti, and Siddique 2017). Apart from purely rational motivations for assimilating in the face of discrimination, there are also psychological ones: ostracism from a group can drive excluded members to reduce investment in group identity, but also often leads to compensatory behavior and extreme identification with the group. The direction of the response is shown to depend on initial degree of group identification (Gómez et al. 2011; Williams and Sommer 1997). This pattern can potentially explain why, for example, Muslims, one of the groups targeted by xenophobic sentiment in the West today, report on average a high degree of identification with their host countries. More than other religions, Muslims in France report feeling closer to French people than members of their own religion or nationality (Dargent 2003), and the vast majority of British-born Muslims identify as British first (Manning and Roy 2010). To the extent that these self-reported identity measures reflect desirability bias, the difference between Muslims and other groups could also be interpreted as a measure of assimilation effort.

The current study moves beyond correlations to identify the causal effect of discrimination on the assimilation decisions of immigrant minorities. Before proceeding, a careful definition of the term discrimination is in order. Discrimination broadly refers to any distinction in favor or against an individual or a group, on the basis of a given characteristic - usually a group-level one-such as race, ethnicity, or religion. It can be institutionalized and carried out by the state or state actors, or it can be informal, and expressed in daily interactions between members of society. Oskooii (2016) calls these two forms of discrimination political and societal. Here, I take the term to mean mostly the latter, and thus encompass any expression of anti-German sentiment, including violent harassment. The distinction between institutionalized and societal discrimination, however, is not that clear in the period under study, since Germans experienced both hostility and various forms of formal discriminatory treatment, such as internment and bans on their press. While such policies may have contributed to the observed effects on assimilation, they are not directly evaluated here, and the more direct measures of discrimination used in this study capture societal discrimination in the form of anti-German sentiment.

\section{WORLD WAR I AND ANTI-GERMANISM IN THE UNITED STATES}

The mass presence of Germans in the US dates back to the 1850s (Conzen 1980). By 1910, they were the largest immigrant group in the country, and unlike the newer arrivals of Eastern and Southern Europeans, they were fairly established and well-integrated. Abramitzky, Boustan, and Eriksson (2014) compute occupationalbased earnings penalties for different nationalities in the US and find first-generation Germans to have one of the lowest differences compared to natives, and one that practically disappears for those who have been in the country for over 30 years. According to Higham (1998),

\begin{abstract}
"Public opinion had come to accept the Germans as one of the most assimilable and reputable of immigrant groups. Repeatedly, older Americans praised them as law-abiding, speedily assimilated, and strongly patriotic... In 1908, a group of professional people, in rating the traits of various immigrant nationalities, ranked the Germans above the English and in some respects judged them superior to the native whites."
\end{abstract}

The outbreak of World War I and Germany's aggressions toward Belgium increased support for the Allies in the US, though did not immediately lead to suspicion against German Americans. In fact, German American leaders, churches, and associations such as the National German American Alliance were vocal supporters of US neutrality in the first years of WWI and campaigned for it with rallies, fundraisers, and bazaars for the German Red Cross (Luebke 1999). Public opinion against Germans in the country first started to shift after the sinking of the ocean liner RMS Lusitania by a German U-boat in 1915, which resulted in the death of hundreds of American passengers. With the entry of the US in the war in 1917, this opinion shift turned into full-blown hostility.

Numerous incidents of harassment of German Americans are recorded during the war period, the most infamous of which was the lynching of Robert Praeger, a German national, by a large mob in Collinsville, Illinois in 1918. Germans all over the country were forced to buy liberty bonds or publicly declare their loyalty to the country by kissing the American flag and denouncing the Kaiser (Luebke 1974). The Bureau of Investigation, and its "citizens' auxiliary" American Protective League, a large network of volunteer spies who numbered 250,000 members in its peak in 1918, mobilized to monitor disloyalty among the German American population. These efforts were assisted by many other nationalist and patriotic organizations of the time, such as the National Security League or the American Defense Society. Thousands of non-naturalized Germans were arrested and interned during WWI (Glidden 1973; Nagler 1993). Moser (2012) finds evidence of discrimination in the New York Stock Exchange, where applications to trade were more frequently rejected when submitted by applicants with German-sounding names. Kazal (2004), in his study of Philadelphia Germans, mentions countless incidents of job loss for individuals who were perceived to be supportive of Germany or to have made disloyal statements. During the peak of anti-German hysteria, states banned the German language in their schools, towns removed German books from libraries, and hamburgers briefly became "liberty steaks."

Most historical sources agree that German Americans responded to this generalized hostility by hiding 
their ethnic identity. Many German associations removed any reference to Germany from their titles, as in the case of Germania Life Insurance Company of New York, which became Guardian Life Insurance Company (Sowell 1996). Germans changed their names to hide their ethnic background. Second-generation Philadelphian German George Washington Ochs (a man with an already rather patriotic first name) changed his last name to Oakes. His petition to the court reads:

"Your petitioner has no purpose or reason in changing the spelling of his father's name, except the desire to relieve his sons of a Teutonic appellation which he believes will arouse hostility and prove an unnecessary burden in their future social, personal, commercial, and professional relations"

(Kazal 2004). Similar motivations drove the actions of many other German Americans. The following sections investigate these behaviors more systematically.

\section{MEASURING ASSIMILATION EFFORT}

I use three proxies of assimilation effort: the first names given by German parents to their US-born children, the numbers of naturalization petitions filed by German immigrants, and Americanization of German immigrants' names in their naturalization documents. In the next section I discuss the reasoning behind the choice of these measures and the datasets used to construct them. I then proceed to outline the empirical strategy. A detailed description of data construction and descriptive statistics can be found in the Online Appendix.

\section{Data}

\section{Children's Names}

The first measure of assimilation effort is naming choices of German parents for their native-born children. Names are markers of culture and have been shown to systematically differ for different ethnic, racial, and social groups (Lieberson 2000; Head and Mayer 2008; Cook, Logan, and Parman 2014). Unlike intermarriage or other indicators of integration that depend on native attitudes and behavior, the naming choice is fully under the control of the parents. Furthermore, to the degree that parents are attached to their culture, choosing a non-ethnic name for one's children is a costly signal of assimilation. Several studies show that there is a labor market penalty associated with foreign-sounding names (Oreopoulos 2011; Algan, Mayer, and Thoenig 2013). ${ }^{1}$ If immigrant parents are aware of this - and extensive name Americanization among immigrants to the US indicates that they are (Biavaschi, Giulietti, and Siddique 2017) - then this penalty can proxy for the monetary value they assign to their children having a name indicative of their ethnic origin.

To capture the ethnic content of names, I compute an index of name distinctiveness that was first used

\footnotetext{
${ }^{1}$ However, Abramitzky, Boustan, and Eriksson (2016) examine the era of mass migration and find no penalty associated with foreign names when comparing pairs of brothers. This indicates that foreign names also capture other family-level unobservables.
}

by Fryer and Levitt (2004), and more recently by Abramitzky, Boustan, and Eriksson (2016) and Fouka (2018), to measure cultural assimilation among immigrants in the US. The index is gender- and ethnicityspecific, and takes on values between 0 and 100, with higher values indicating names that are more distinctive of a specific ethnic origin. I call this index Foreign Name Index (FNI), and calculate it based on the empirical frequency of names that appear in the complete-count 1930 census (Minnesota Population Center and Ancestry.com 2013), for US-born men of foreign-born fathers. ${ }^{2}$

Figure 1 shows averages of the FNI by ethnicity in the census data. Table 1 lists the names with the highest FNI encountered at least 1,000 times among secondgeneration Germans in the subset of people born before (left panel) and after (right panel) the US entered World War I. While most names are distinctively German, they become less so after 1917. This partly captures a general assimilation trend among Germans in the US, but, as will be shown later, it is also reflective of a sharper break around the start of the war, which was not experienced by other immigrant groups.

\section{Naturalization Petitions}

The second outcome I examine is the number of petitions for naturalization filed by German nationals during and after the war. The decision to apply for citizenship is a signal of assimilation, and a particularly costly one for Germans, who would have to renounce their German citizenship in order to become American. ${ }^{3}$ In 1906, the path to citizenship for immigrants was standardized by the Bureau of Immigration and Naturalization, and most naturalization cases were handled by federal courts. Immigrants would usually file a Declaration of Intention (known as "first papers") upon arrival or shortly thereafter. Within five years, they were eligible to file a Petition for Naturalization ("second papers"), which was the last step required of the immigrant before the court finalized the naturalization process. I focus on petitions rather than declarations of intention, because the former are the most consequential step in the naturalization process and because declarations are not available independently, but only attached to collections of associated petitions.

Unlike actual rates of naturalization, naturalization petitions are a good proxy for assimilation effort because they allow for a separate observation of the decision of the immigrant to apply for citizenship from the decision of the courts to grant it. In Section C of the Online Appendix, I present results using naturalization rates instead of petitions and I demonstrate that there was

\footnotetext{
${ }^{2}$ Because the FNI is gender-specific, I focus on male names, which are more ethnically distinctive than female ones. In the Online Appendix I replicate the main analysis for women. All results go through.

3 According to the 1913 "Nationality Law of the German Empire and States" (Reichs- und Staatsangehörigkeitsgesetz-RuStAG), which was operational in Germany until 1999. Jones-Correa (2001) finds that US naturalization rates are higher among nationals of countries that allow dual citizenship. Using naturalization rates of German citizens is thus a particularly hard test for detecting assimilation responses.
} 


\section{FIGURE 1. Foreign Name Index (FNI) by Ethnicity for Second-Generation Immigrant Men Born} 1880-1930

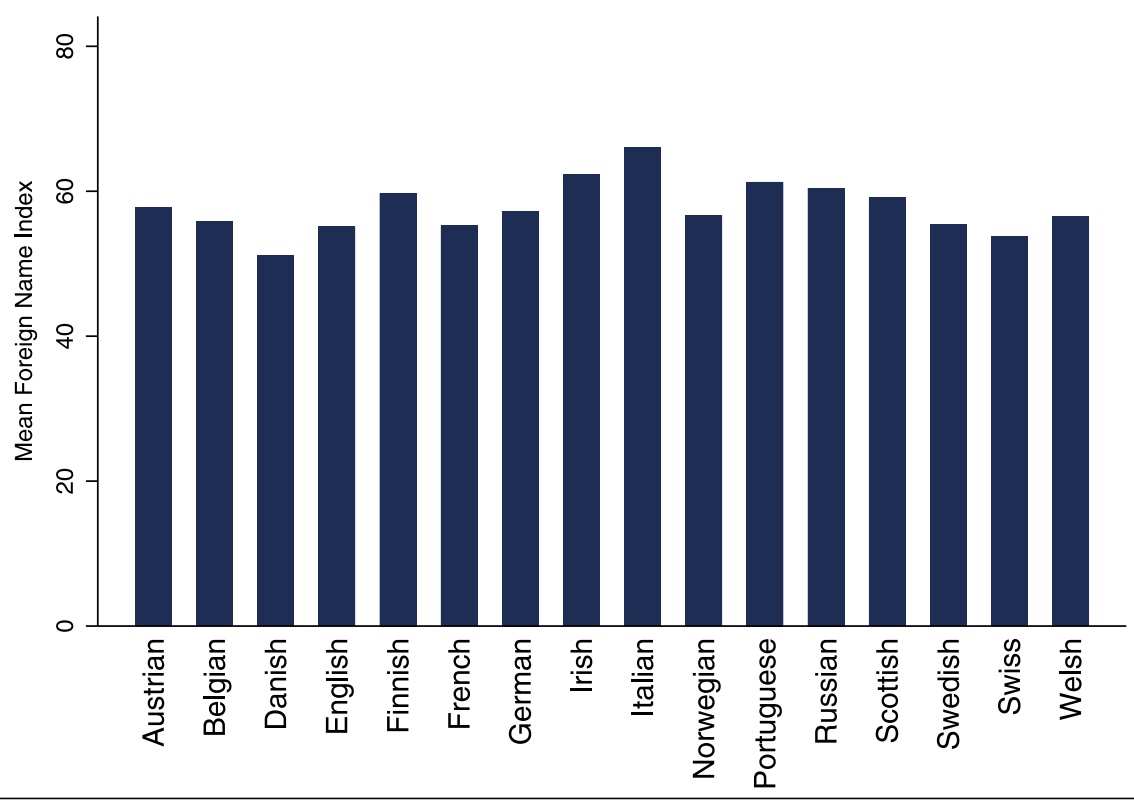

\section{TABLE 1. Most German Names Before and After World War I}

\begin{tabular}{|c|c|c|c|}
\hline \multicolumn{2}{|c|}{ Before 1917} & \multicolumn{2}{|c|}{ After 1917} \\
\hline Name & FNI & Name & $\mathrm{FNI}$ \\
\hline Fritz & 94.46 & Otto & 93.25 \\
\hline Hugo & 93.81 & Herman & 89.17 \\
\hline Ernst & 93.41 & Frederick & 81.18 \\
\hline Gustav & 93.30 & Fred & 79.90 \\
\hline August & 93.16 & Henry & 78.25 \\
\hline Otto & 92.92 & Carl & 75.94 \\
\hline Herman & 92.19 & Albert & 68.79 \\
\hline Gustave & 92.03 & Ernest & 67.84 \\
\hline Conrad & 91.22 & Louis & 67.59 \\
\hline Ferdinand & 90.93 & Bernard & 64.73 \\
\hline
\end{tabular}

substantial delay in the processing of petitions filed by Germans during the war years. This is evidence of discretion exercised by the courts that varied by nationality, and it validates the use of petitions as a better proxy of immigrants' decisions than actual naturalization counts.

I use data on the number of petitions filed by immigrants between 1911 and 1925 from the genealogical website Ancestry.com. Ancestry makes available a large catalog of digitized images of naturalization petitions from several US states, searchable online via a number of criteria. I create counts of petitions filed by nationality, year of petition and state in which the petition was filed. The unit of observation in the final dataset is a nationality-year-state cell. Information is available for four states: California, Maryland, Pennsylvania, and
Virginia. Although the collection of Ancestry contains records from other states as well, it is only for these four states that one is able to search separately for naturalization petitions as opposed to other naturalization documents that are less relevant to the pertinent study question, such as certificates of arrival and naturalization certificates issued after a petition has been approved. Yet the characteristics of German immigrants in these four states are very similar to the German population nationwide (Table B.3 in the Online Appendix).

\section{Name Changes Among Immigrants}

Unlike names chosen for US-born children of Germans, name changes among the foreign-born cannot be 
examined using census data. To create a measure of name Americanization, I use detailed information from naturalization records. A large number of immigrants changed their names while filing to obtain the US citizenship, and the available records (certificate of arrival, declaration of intention and petition) allow us to observe those name changes over time.

I compile a sample of 3,101 naturalization records from the collections of the District Court for the Eastern Division of the Northern District of Illinois, and the District Court for the Eastern District of Pennsylvania, which have been made publicly available in the form of scanned images by FamilySearch.org. Such collections are only available for few other states. Illinois and Pennsylvania were chosen because they had a high share of German immigrants $(26 \%$ and $13 \%$ of all foreign-born in 1910) and are also broadly representative of the German population in the country as a whole (Table B.3 in the Online Appendix).

For each year between 1911 and 1925, I extract a 1\% random sample of the total number of naturalization petitions filed in that year in the state, as reported in the Annual Reports of the Commissioner of Naturalization (US Department of Labor, Bureau of Naturalization 1913-1923). Together with each petition, I transcribe the corresponding declaration of intention and certificate of arrival whenever available. This dataset allows me to observe the entire naturalization process and the evolution of applicants' characteristics, including reported names, over time.

In practice, the vast majority of immigrants who chose to Americanize their names did so at the time they filed a declaration of intention, with only a very small proportion changing their name between declaration and petition. ${ }^{4}$ For this reason, I focus on declarations of intention filed after 1911 and examine name Americanization at the time of declaration. This restricted focus inevitably reduces the sample size, because only 1,464 individuals have a complete set of records that includes both the certificate of arrival and later naturalization papers.

To systematically assess name Americanization as a proxy for assimilation effort, I combine the names of immigrants in the above naturalization records with information from the $1 \%$ sample of the Integrated Public Use Microdata Series of the 1920 and 1930 Census (IPUMS) (Ruggles et al. 2010) to create an Americanization Index (AMI), following Biavaschi, Giulietti, and Siddique (2017). This index captures the frequency of a name in the American-born population, and is thus a measure of conformity with American naming norms. ${ }^{5}$ An increase in the AMI from the time of arrival to the US to the time an immigrant files his or her first papers denotes the adoption of a name that is more common among native-born Americans than the immigrant's given name. In practice, that is often the

\footnotetext{
${ }^{4}$ In the sample, there are only 86 (out of 3,101 ) cases of first name changes at the time of petition.

${ }^{5}$ For a comparison of the AMI and FNI, and the advantages of using the former to assess name Americanization, see Section A.2 in the Online Appendix.
}

Americanized version of a foreign name (e.g., a change from Josef to Joseph), but it can also be an unrelated generic American name (e.g., a change from Utka to Louis). In the analysis, I use as dependent variables both a binary and a continuous measure of the change in AMI, as well as the AMI itself. ${ }^{6}$ To account for the fact that the declaration and petition documents were often filled out by a clerk and not by the immigrant herself, I create the index both for the actual name, and its Soundex phonetic equivalent. The Soundex assigns the same code to names that are pronounced similarly, but have a different spelling, such as Jon and John.

\section{Empirical Strategy}

In analyzing the evolution of all three measures of assimilation effort, my empirical strategy amounts to a difference-in-differences specification of the form:

$$
Y_{i g c}=\alpha+\beta T_{i g c}+\lambda_{g}+\theta_{c}+\varepsilon_{i g c},
$$

where $Y_{i g c}$ is the outcome of interest (the FNI of the children of immigrants, the number of naturalization petitions, or the AMI of names of immigrant petitioners). $i$ indexes individuals, $g$ indexes nationalities and $c$ indexes birth cohorts (in the case of the FNI) or years of filing (in the case of petition counts and of the AMI). $T_{i g c}$ is an indicator for "treated" individuals. In the case of the FNI, it indicates US-born individuals of German-born parents born in or after 1917, the year when the US entered World War I. In the case of the other two outcomes it indicates German nationals who filed a petition (or, in the case of the AMI, a declaration of intention) in or after 1917. $\lambda_{g}$ and $\theta_{c}$ are nationality and birth cohort (or year, in the case of naturalization documents) fixed effects, respectively. The interaction coefficient $\beta$ captures the differential effect of World War I on the outcome of interest.

\section{RESULTS}

\section{Main Estimates}

The main finding is illustrated in Figure 2. There is a clear assimilation trend in the average FNI of secondgeneration Germans throughout the period of reference from 1880 on, which is, however, punctuated by a break coinciding with the entry of the US in the war. A similar pattern is revealed by the evolution of the median FNI: this is fairly stable between 1895 and 1918, at which point it drops precipitously and remains at a low level until the late 1920s.

Figure 3 presents a more systematic identification of a breakpoint in the FNI time series. The figure plots $p$-values from a Wald test for a break in the linear trend in each of the years 1905-1925. A range of low $p$-values identifies the period after 1918 as a structural break in

\footnotetext{
${ }^{6}$ I use the natural logarithm of the AMI to account for the fact that the index has a skewed distribution with a mass at zero. To avoid loss of data when $\mathrm{AMI}=0$, I use $\ln (\mathrm{AMI}+x)$, where $x$ is a small positive number. Results are robust to using levels instead of logs.
} 
FIGURE 2. Mean and Median FNI of Second-Generation German Men
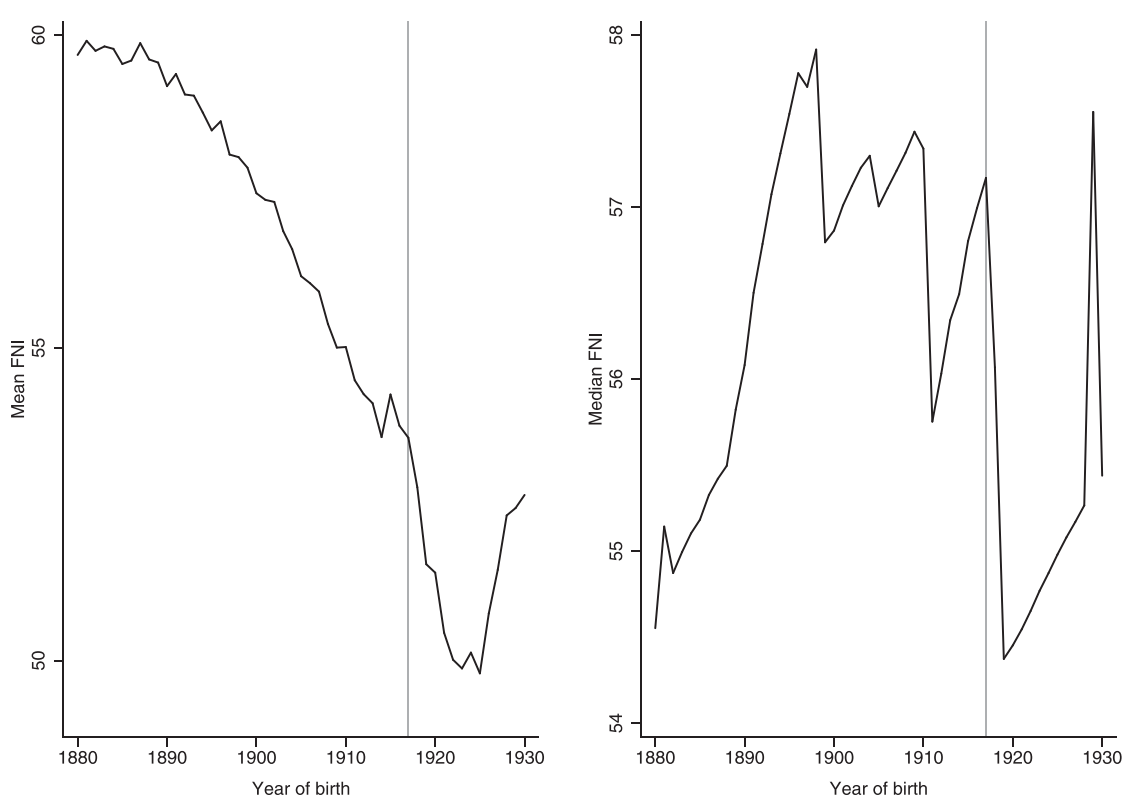

Notes: The vertical lines correspond to 1917.

naming patterns. The sharp reaction of names to the war validates their use as a measure of assimilation effort that reflects a choice on the part of the parents. A slow response of naming patterns to the war could reflect, for example, changes in intermarriage rates among Germans, which could be endogenous to native attitudes. Instead, an abrupt change is more consistent with a change in immigrant behavior.

I then compare Germans to other ethnic groups in the US. Table 2 reports the results of a difference-indifferences estimation, as specified in equation (1). Column (1) is a comparison between cohorts born before and after 1917 across Germans and other ethnicities. Column (2) additionally controls for a linear trend in naming patterns. Germans have on average a lower FNI than other ethnic groups. This partly reflects the overlap in naming patterns among Germans and other ethnicities, such as Anglo-Saxons or Scandinavians, and partly the fact that many third- or higher generation Germans with potentially Germansounding names are classified as natives in the census. This was less likely for less-established immigrant groups. The interaction coefficient indicates a higher drop in the FNI for Germans born during and after WWI. Columns (3) and (4) progressively introduce birth cohort and ethnicity fixed effects. The magnitude of the interaction coefficient implies a change equivalent to that from Werner or Julius - both names in the 90th percentile of the pre-war FNI distribution - to a name such as Carl, the Americanized version of the German Karl that is much less indicative of a German origin. To account for potential differences in naming trends across ethnicities, in column (5), I use as a dependent variable the residual of the FNI from a linear ethnicity-specific trend, fitted to the pre-war period.
While this reduces the size of the coefficient, the effect of the war remains large and significant. In column (6), I control for state-of-birth fixed effects. This does not change the estimated interaction effect by much. ${ }^{7}$

These effects on German naming patterns are substantial. Already in the pre-war period, Germans were experiencing a prolonged trend of name assimilation. Yet during the three years between 1917 and 1920, the FNI sank as much as it had during the ten years prior to the war. The German distinctiveness of first names was dropping by 0.26 index points on average in the 30 years before the war. During 1917-20 this rate more than tripled. The effect is also sizable compared to other groups. In 1914, the Danish, the group with the least distinctive naming patterns, had an average FNI that was nearly three index points lower than that of Germans. By 1920 this difference was cut by more than half.

An intuitive way to evaluate changes in the FNI is by considering how reliably a name reveals the nationality of the bearer. Given that Germans constituted $5.89 \%$ of the total population in 1930, the pre-war FNI of 59.60 implies that a randomly chosen German with a name of average FNI could be identified as German with $8.45 \%$ probability. The results of Table 2 imply that the average German name became significantly less revealing after the war. Estimates from column 4 imply a reduction in the probability of identifying a name of average FNI as German by almost 2 percentage points to a probability of $6.75 \%$.

The pattern revealed by naturalization petitions is similar to that of names. Table 3 compares the numbers of

\footnotetext{
${ }^{7}$ Results are even stronger for women. See Table D.2 in the Online Appendix.
} 
FIGURE 3. Testing for a Trend Break in the FNI of Second-Generation Germans

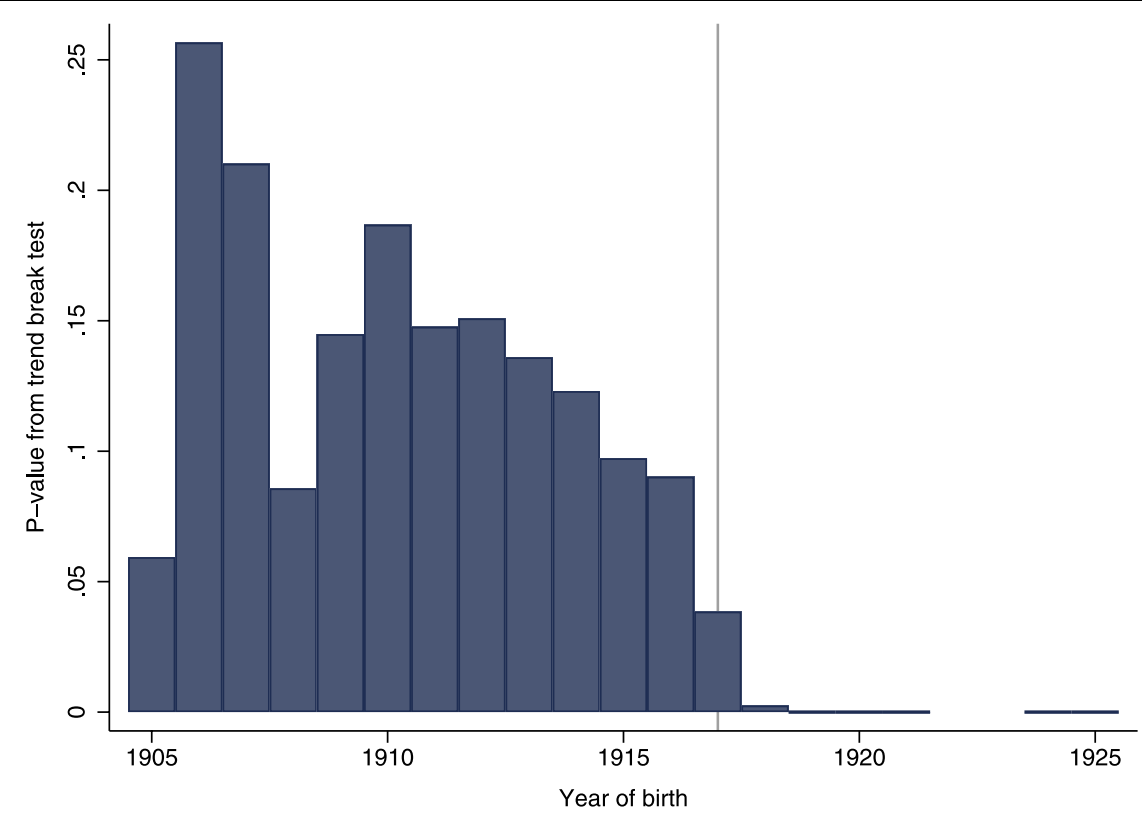

Notes: The figure plots $p$-values from a Wald test of a break in the linear trend over the period 1905 to 1925 . The vertical line corresponds to 1917.

TABLE 2. World War I and Naming Patterns

FNI (Mean: 59.597)

\begin{tabular}{|c|c|c|c|c|c|c|}
\hline Dep. variable: & [1] & [2] & [3] & [4] & [5] & [6] \\
\hline German & $\begin{array}{c}-1.872^{\star * *} \\
(0.0217)\end{array}$ & $\begin{array}{c}-1.581^{* * *} \\
(0.0222)\end{array}$ & $\begin{array}{c}-1.460^{* * *} \\
(0.0223)\end{array}$ & & & \\
\hline Born 1917 or later & $\begin{array}{c}1.540^{\star \star *} \\
(0.0240)\end{array}$ & $\begin{array}{c}0.366^{\star * *} \\
(0.0331)\end{array}$ & & & & \\
\hline German $\times$ born 1917 or later & $\begin{array}{c}-8.042^{\star \star \star} \\
(0.0607)\end{array}$ & $\begin{array}{c}-8.316^{\star \star \star} \\
(0.0608)\end{array}$ & $\begin{array}{c}-8.512^{\star \star \star} \\
(0.0609)\end{array}$ & $\begin{array}{c}-5.955^{\star \star \star} \\
(1.751)\end{array}$ & $\begin{array}{r}-3.069^{*} \\
(1.640)\end{array}$ & $\begin{array}{r}-2.931^{*} \\
(1.643)\end{array}$ \\
\hline $\begin{array}{l}\text { Observations } \\
R \text {-squared }\end{array}$ & $\begin{array}{r}6,495,803 \\
0.00551\end{array}$ & $\begin{array}{r}6,495,803 \\
0.00593\end{array}$ & $\begin{array}{r}6,495,803 \\
0.00680\end{array}$ & $\begin{array}{c}6,495,803 \\
0.0309\end{array}$ & $\begin{array}{r}6,495,803 \\
0.00554\end{array}$ & $\begin{array}{r}6,495,803 \\
0.0158\end{array}$ \\
\hline
\end{tabular}

Linear time trend

Year of birth FE

Ethnicity FE

Linear ethnicity trends

State of birth FE

$\begin{array}{ll}N & Y \\ N & N \\ N & N \\ N & N \\ N & N\end{array}$

$\begin{array}{ll}N & N \\ Y & Y \\ N & Y \\ N & N \\ N & N\end{array}$

$\begin{array}{ll}N & N \\ Y & Y \\ Y & Y \\ Y & Y \\ N & Y\end{array}$

Notes: The dataset consists of all men born in the US 1880-1930 to a foreign-born father. The dependent variable in columns (5)-(6) is the residual from a regression of the FNI on linear ethnicity-specific trends fitted to the pre-war period. Heteroscedasticity-robust standard errors are reported in columns (1)-(3), and robust standard errors clustered at the ethnic group level are reported in columns (4)-(6). Significance levels: ${ }^{\star \star \star} p<0.01,{ }^{\star \star} p<0.05,{ }^{\star} p<0.1$.

petitions filed by Germans and other nationalities before and after the war. Germans file more petitions for naturalization on average, which could be because of their larger numbers or the fact that they were more assimilated than other immigrant groups. The interaction coefficient is also positive, implying that the difference between Germans and other nationalities in the number of petitions filed increases after 1917. Depending on the specification, the differential increase in petitions filed by Germans is between 37 and 40 petitions per state and year. This represents a more than $100 \%$ increase in the pre-war average of approximately 35 petitions per state and year. The total effect in all four states amounts to an additional 1,330 to 1,426 petitions. This implies that close 
TABLE 3. Petitions for Naturalization

\begin{tabular}{|c|c|c|c|c|c|c|}
\hline \multirow[b]{2}{*}{ Dep. variable: } & \multicolumn{6}{|c|}{ Number of petitions (Mean: 56.051) } \\
\hline & [1] & [2] & [3] & [4] & {$[5]$} & [6] \\
\hline German & $\begin{array}{c}29.39^{\star \star *} \\
(8.832)\end{array}$ & $\begin{array}{c}29.33^{\star \star *} \\
(8.788)\end{array}$ & $\begin{array}{c}29.37^{\star \star *} \\
(8.868)\end{array}$ & & & \\
\hline After 1917 & $\begin{array}{c}23.12^{\star * \star} \\
(4.730)\end{array}$ & $\begin{array}{c}-0.474 \\
(6.273)\end{array}$ & & & & \\
\hline German × after 1917 & $\begin{array}{c}39.61^{* * *} \\
(4.730)\end{array}$ & $\begin{array}{c}40.28^{\star \star *} \\
(4.603)\end{array}$ & $\begin{array}{c}40.38^{\star \star *} \\
(4.561)\end{array}$ & $\begin{array}{c}38.31^{\star * \star} \\
(4.388)\end{array}$ & $\begin{array}{c}37.00^{* * *} \\
(5.389)\end{array}$ & $\begin{array}{c}38.04^{\star \star \star} \\
(7.919)\end{array}$ \\
\hline $\begin{array}{l}\text { Observations } \\
R \text {-squared }\end{array}$ & $\begin{array}{c}950 \\
0.0561\end{array}$ & $\begin{array}{l}950 \\
0.0594\end{array}$ & $\begin{array}{c}950 \\
0.0640\end{array}$ & $\begin{array}{c}950 \\
0.235\end{array}$ & $\begin{array}{c}950 \\
0.486\end{array}$ & $\begin{array}{c}950 \\
0.361\end{array}$ \\
\hline Linear time trend & $\mathrm{N}$ & $\mathrm{Y}$ & $\mathrm{N}$ & $\mathrm{N}$ & $\mathrm{N}$ & $\mathrm{N}$ \\
\hline Year FE & $\mathrm{N}$ & $\mathrm{N}$ & $\mathrm{Y}$ & $\mathrm{Y}$ & $\mathrm{Y}$ & $\mathrm{Y}$ \\
\hline Country of origin FE & $\mathrm{N}$ & $\mathrm{N}$ & $\mathrm{N}$ & $\mathrm{Y}$ & $\mathrm{Y}$ & $\mathrm{Y}$ \\
\hline Residence state FE & $\mathrm{N}$ & $\mathrm{N}$ & $\mathrm{N}$ & $\mathrm{N}$ & $\mathrm{Y}$ & $\mathrm{Y}$ \\
\hline Linear nationality trends & $\mathrm{N}$ & $\mathrm{N}$ & $\mathrm{N}$ & $\mathrm{N}$ & $\mathrm{N}$ & $\mathrm{Y}$ \\
\hline
\end{tabular}

to $6 \%$ of the approximately 25,000 non-naturalized Germans who lived in these states in 1910 rushed to apply for citizenship between 1917 and 1925 .

Figure 4 plots the interaction coefficient from a flexible specification similar to the one in column (5) of Table 3 but with interactions of an indicator for German nationals with year fixed effects. The figure reveals a general absence of pre-trends before 1917. After the US enters the war, the number of petitions increases differentially for Germans, and this increase is sustained until 1925. The figure also reveals a large differential drop in the year 1918: in this year, the US granted citizenship through expedited naturalization procedures to a large number of foreign-born soldiers who enlisted in the US Army. The expedited process waived the residency requirement, thus the obligation to file a declaration of intention, and allowed many soldiers to become naturalized on the same day in which they filed their petition. This exceptional provision did not apply to non-naturalized Germans, who were considered "enemy aliens" under the Alien and Sedition Acts of 1798, which were invoked by President Wilson (Kazal 2004). To deal with this exceptional increase in the number of petitions for everyone but Germans in 1918, all regressions include an indicator for Germans in the year 1918. Regressions in columns (1) and (2) of Table 3 that do not include year fixed effects nonetheless include a 1918 year indicator.

Table 4 presents the results for name Americanization. Columns (1) and (2) look at the change in a name's conformity to American norms between arrival and declaration. In both cases, I control for the logarithm of a name's AMI at the time of arrival. Immigrants with names closer to the American norm would have less of an incentive to Americanize their name. Column
(3) shows that names of Germans who file a declaration of intention become on average more American after 1917. Irrespective of the measure used, Germans tend to change their names to an Americanized counterpart disproportionately more than other immigrants after 1917. Depending on the measure, the effect amounts to an additional 6.9 to $9.9 \%$ of Germans Americanizing their name, which corresponds to an increase of $16-38 \%$ of the respective long term average. Results using the Soundex are presented in columns (4)-(6) and are similar in direction and magnitude.

Figure 5 plots the coefficients on indicators for every two-year bin in the data, resulting from a regression otherwise identical to that in column (2) of Table 4. First names do not show any noticeable change at the outbreak of WWI in Europe but become significantly Americanized in 1917-1918. This effect does not carry over to the post-war years, though estimates for years other than 1917 are noisy, because declarations filed by Germans are disproportionately concentrated in that year $(22 \%$ of the total, compared to $1-11 \%$ for every other year). Overall, these patterns in name changes are consistent with those found among the second generation and indicate that Germans responded to the war with efforts to hide their identity and send signals of patriotism.

\section{Ruling out Alternative Explanations}

The above findings suggest that assimilation efforts are positively correlated with general hostility. There are other complementary explanations of the results. One is return migration to Germany. Bandiera, Rasul, and Viarengo (2013) find the out-migration rate of Germans in the decade $1910-1920$ to be higher than $100 \%$. If 
FIGURE 4. Evolution of German Petitions for Naturalization

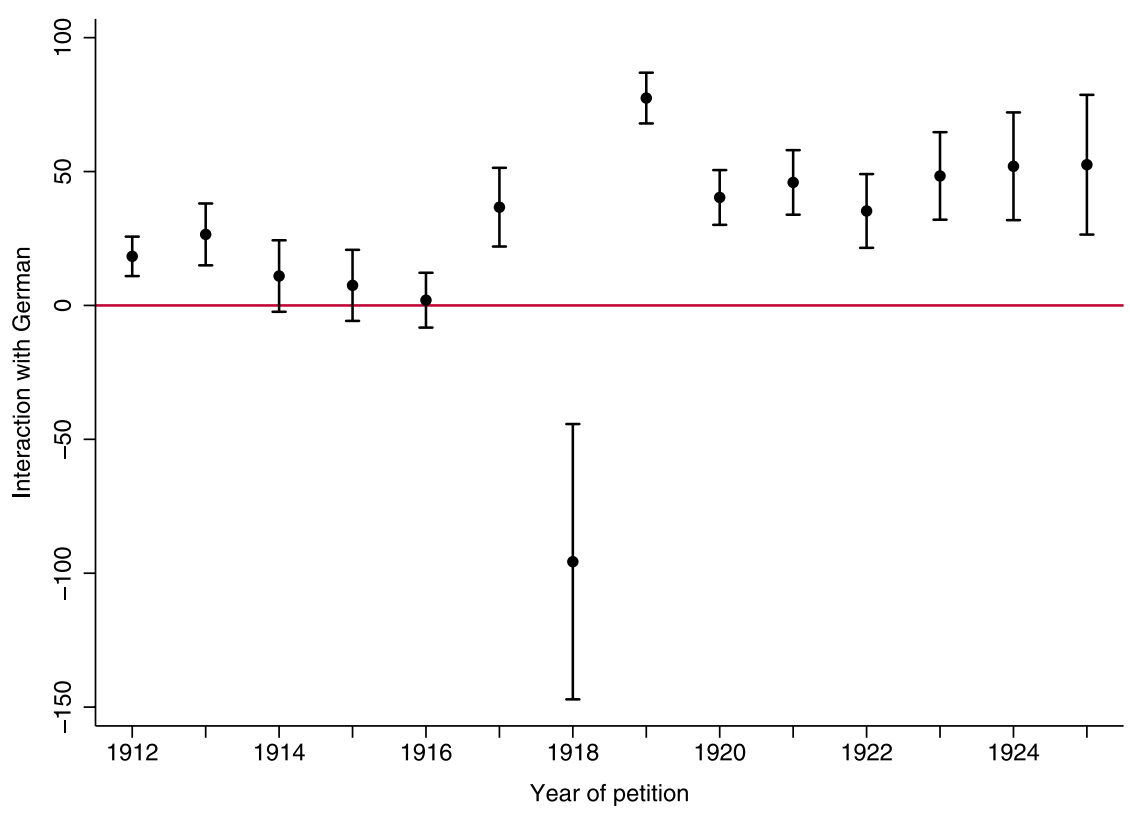

Notes: The figure reports coefficient estimates and $90 \%$ confidence intervals from a regression of the total number of petitions by nationalityyear-state cell on nationality, year, and state fixed effects and interactions of year indicators with a dummy for petitions filed by Germans.

TABLE 4. Name Americanization

\begin{tabular}{|c|c|c|c|c|c|c|}
\hline \multirow[b]{2}{*}{ Dep. variable: } & \multicolumn{3}{|c|}{ First name } & \multicolumn{3}{|c|}{ Soundex phonetic equivalent } \\
\hline & $\begin{array}{c}\text { Log AMI higher in } \\
\text { declaration than at arrival } \\
{[1]}\end{array}$ & $\begin{array}{c}\text { Change in } \\
\text { log AMI } \\
{[2]}\end{array}$ & $\underset{[3]}{\log A M I}$ & $\begin{array}{c}\text { Log AMI higher in } \\
\text { declaration than at arrival } \\
{[4]}\end{array}$ & $\begin{array}{c}\text { Change in } \\
\text { log AMI } \\
{[5]}\end{array}$ & $\underset{[6]}{\log A M I}$ \\
\hline $\begin{array}{l}\text { German } \times \text { after } \\
1917\end{array}$ & $\begin{array}{l}0.0689^{\star \star \star} \\
(0.0182)\end{array}$ & $\begin{array}{l}0.529^{\star \star \star} \\
(0.176)\end{array}$ & $\begin{array}{l}0.484^{\star *} \\
(0.176)\end{array}$ & $\begin{array}{l}0.0989^{\star \star \star} \\
(0.0241)\end{array}$ & $\begin{array}{l}0.381^{\star \star \star} \\
(0.126)\end{array}$ & $\begin{array}{l}0.754^{\star \star *} \\
(0.0793)\end{array}$ \\
\hline $\begin{array}{l}\text { Observations } \\
R \text {-squared } \\
\text { Mean dep. var. }\end{array}$ & $\begin{array}{l}1,464 \\
0.381 \\
0.415\end{array}$ & $\begin{array}{l}1,464 \\
0.383 \\
2.358\end{array}$ & $\begin{array}{r}2,532 \\
0.246 \\
-4.689\end{array}$ & $\begin{array}{l}1,464 \\
0.282 \\
0.261\end{array}$ & $\begin{array}{l}1,464 \\
0.358 \\
0.840\end{array}$ & $\begin{array}{r}2,532 \\
0.137 \\
-3.121\end{array}$ \\
\hline
\end{tabular}

those less assimilated move out of the country, leaving the more assimilated behind, then both Americanization of children's names and petitions for naturalization would increase. ${ }^{8}$

\footnotetext{
${ }^{8}$ The concern is in fact slightly more subtle. Using the 1930 census already implies that I only observe the selected sample of families who did not emigrate in 1918. However, even within this sample, those with children born right before the war were likely more constrained and less able to emigrate. For this subset, selection is less important than for those without young children who could emigrate at will. One would then expect that children born after 1917 come from more assimilated parents, a pattern that is confirmed in the data. Second-generation Germans born after 1917 are more likely to have parents who have been in the country for longer and who are naturalized US citizens.
}

To directly assess whether assimilation during wartime can be entirely explained away by selective outmigration, I exploit the fact that census data on family interrelationships and year of birth allows me to observe, for a subset of families, children born both before and after the war. Comparing differences in the FNI of older and younger siblings for Germans and other nationalities allows me to isolate the effect of wartime hostility on parental decisions while keeping the sample composition constant. For this purpose, I restrict my attention to a subset of the 1930 census, which consists of sons who live with their parents and with at least one male sibling at the time of the census. For this subset, I estimate a specification identical to equation (1), only now including a 


\section{FIGURE 5. Change in AMI Between Arrival and Declaration}

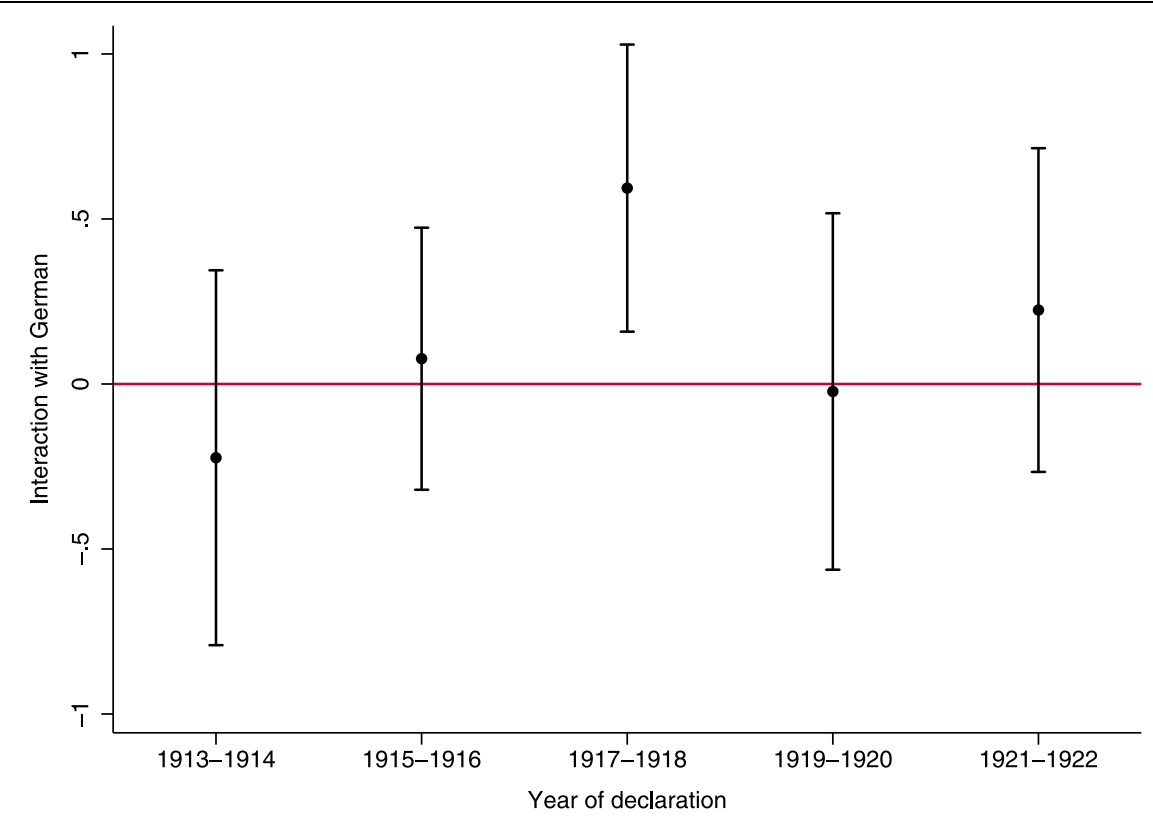

Notes: The figure reports coefficient estimates and $90 \%$ confidence intervals from a regression of the change in the log AMI between arrival and declaration on indicators for nationality and two-year bins of declaration indicators and a set of interactions of two-year bins with an indicator for German nationals. The regression controls for the log AMI of the first name in the certificate of arrival. The sample consists of immigrants who filed a declaration of intention between 1911 and 1923 in the Northern Illinois and Eastern Pennsylvania district courts.

family fixed effect. To the extent that out-migration distorted the characteristics of the population of Germans that chose to remain in the US, this specification will account for this distortion by considering changes in naming patterns within a family over time.

Table 5 presents the results. Column (1) reports the baseline specification in the restricted subset of families with more than one male child present in the household at the time of the census. The effect of the war on names is generally smaller yet comparable to that in the larger dataset reported in Table 2. Columns (2) to (5) introduce family fixed effects. The within-family effect is a bit over half in magnitude, which implies that changes in the composition of the German population over time are largely responsible for the observed assimilation patterns. Inclusion of fixed effects, however, is not enough to explain away the entire effect, which remains positive and highly significant. The estimated coefficient implies that the probability of identifying a name of median FNI as German drops from $8.53 \%$ to $7.82 \%$. This suggests that even after accounting for out-migration, families of Germans who remained in the US did change their naming decisions in response to the war. Inclusion of indicators for an individual's state of birth, birth order, or father's arrival cohort have only a marginal effect on the magnitude of the coefficient.

In Section D.5 of the Online Appendix I rule out a number of other potential alternative explanations for the observed patterns. In particular, I show that the differential increase in naturalization petitions filed by Germans is not due to larger numbers of incoming
German immigrants relative to other immigrant groups. I also show that naming and naturalization patterns cannot be explained by the immigration restrictions imposed between 1917 and 1924. Finally, I provide evidence that the changes in the behavior of Germans cannot be attributed simply to altered incentives to assimilate in response to the war. Immigrants from countries that remained neutral during WWI, but who faced similar hostility in the US, such as Scandinavians, show similar changes in naming patterns.

\section{State-Level Anti-German Sentiment}

So far, I have not measured discrimination against Germans directly. Actual discriminatory treatment-especially in its subtler, non-institutionalized and non-violent expressions-is hard to measure, which is why the vast majority of studies in political science and social psychology measure instead perceptions of discrimination (DeSipio 2002; Oskooii 2016; Schildkraut 2005), or take advantage of time variation that leads to changes in sentiment and behavior against a group, even when those changes cannot be quantified directly (Cho, Gimpel, and Wu 2006; Pantoja, Ramirez, and Segura 2001). ${ }^{9}$ While the latter approach is used throughout the

\footnotetext{
${ }^{9}$ Audit and resumé studies (Bertrand and Mullainathan 2004; Butler and Broockman 2011; Fix and Turner 1998; Goldin and Rouse 2000; Oreopoulos 2011) are an exception. In the case of German Americans during WWI, Moser (2012) has measured discrimination directly, but only in the narrow context of the NYSE.
} 
TABLE 5. Accounting for Out-Migration

FNI (Mean: 59.826)

\begin{tabular}{lccccc}
\cline { 2 - 5 } Dep. variable: & {$[1]$} & {$[2]$} & {$[3]$} & {$[4]$} & {$[5]$} \\
\hline German $\times$ born 1917 or later & $-4.012^{* \star}$ & $-2.136^{\star \star \star}$ & $-2.143^{* \star *}$ & $-2.275^{\star \star \star}$ & $-2.317^{\star * \star}$ \\
& $(1.595)$ & $(0.563)$ & $(0.556)$ & $(0.607)$ & $(0.610)$ \\
Observations & $2,462,651$ & $2,462,651$ & $2,462,651$ & $2,462,651$ & $2,195,152$ \\
$R$-squared & 0.0490 & 0.498 & 0.498 & 0.498 & 0.497 \\
Family FE & $\mathrm{N}$ & $\mathrm{Y}$ & $\mathrm{Y}$ & $\mathrm{Y}$ & $\mathrm{Y}$ \\
State of birth FE & $\mathrm{N}$ & $\mathrm{N}$ & $\mathrm{Y}$ & $\mathrm{Y}$ & $\mathrm{Y}$ \\
Birth order FE & $\mathrm{N}$ & $\mathrm{N}$ & $\mathrm{N}$ & $\mathrm{Y}$ & $\mathrm{Y}$ \\
Father's arrival cohort FE & $\mathrm{N}$ & $\mathrm{N}$ & $\mathrm{N}$ & $\mathrm{N}$ & $\mathrm{Y}$ \\
\hline
\end{tabular}

Notes: The dataset consists of all men born in the US 1880-1930 to a foreign-born father, who live in the same household as their father and at least one male sibling at census time. All regressions include birth year and ethnicity indicators. Standard errors are clustered at the ethnicity level. Significance levels: ${ }^{* *} p<0.01,{ }^{* *} p<0.05,{ }^{*} p<0.1$.

paper, here I attempt to measure anti-Germanism more directly at the state level. I construct two measures of anti-German sentiment. The first measure is based on patterns of support for Democratic incumbent Woodrow Wilson in the 1916 Presidential election. While it captures more than anti-German hostility, it has the advantage of being constructed from data consistently available for all states. The second one is based on incidents of violent harassment against Germans, as reported in the news. It is a more accurate proxy of native hostility, but potentially subject to reporting bias. Encouragingly, results from both measures point in the same direction. Details on their construction are provided in Section A of the Online Appendix.

President Wilson's campaign against "hyphenated Americans," which intensified during his second term in office and the country's entry in WWI, is best illustrated by his 1915 State of the Union address;

"There are citizens of the United States, ... born under other flags but welcomed under our generous naturalization laws to the full freedom and opportunity of America, who have poured the poison of disloyalty into the very arteries of our national life." Such men, he advised Congress, "must be crushed out ... the hand of our power should close over them at once."

The Wilson administration and the President himself openly supported the anti-hyphen movement that after 1917 manifested in acts of harassment and violence against German Americans suspected of disloyalty. As a result, the states that did not support Wilson in 1916 were disproportionately concentrated in the Midwest and Great Plains, all regions with large German American populations. Indeed, German Americans in their majority rallied behind the Republican candidate Charles E. Hughes (Luebke 1974).

Figure 6 plots the median FNI by birth cohort for states with below- and above-median change in support for Wilson in 1916. The pattern is once again striking: while the trends are roughly parallel before the war,
1918 constitutes a break in the trend for both groups of states, but is more pronounced in states that showed a higher increase in support for Wilson, thus expressing more pro-war and anti-German sentiment.

Panel A of Table 6 analyzes the same pattern more systematically in a difference-in-differences framework, comparing how the difference in the FNI of Germans born before and after the war varies by the change in vote shares for Wilson in 1916. The interaction coefficient is consistently negative, denoting a substantially larger drop in German-sounding names after the war in states where anti-German sentiment was more prevalent. The difference between the two sets of states is almost twice the size of the original effect, confirming that the bulk of the observed total effect comes from states with above-median change in support for Wilson. In column (2), I control for the potential time-varying effect of the share of the German population in the state, which is plausibly correlated with both (lower) support for Wilson and assimilation. I insert interactions of birth cohort fixed effects with the 1910 share of first- and second-generation Germans in a state's total population, computed from county-level census totals (Haines and ICPSR 2010). The inclusion of these controls increases both the magnitude and the precision of the estimate. While the change in native attitudes toward Germans spurred by the war can be considered exogenous in the aggregate, state-level anti-Germanism is potentially endogenous to preexisting trends in German assimilation. In an attempt to control for pre-war assimilation of Germans at the state level, in column (3), I include interactions of birth cohort fixed effects with the average FNI among secondgeneration Germans born in each state before 1914. This is meant to capture any time-varying differential effects on the FNI of pre-existing assimilation measured using the same proxy of names. This control does not affect the estimates. In column (5), I include stateof-birth-specific linear trends. While these seem to explain part of the differential changes in naming 
FIGURE 6. Evolution of Naming Patterns and State-Level Support for Woodrow Wilson

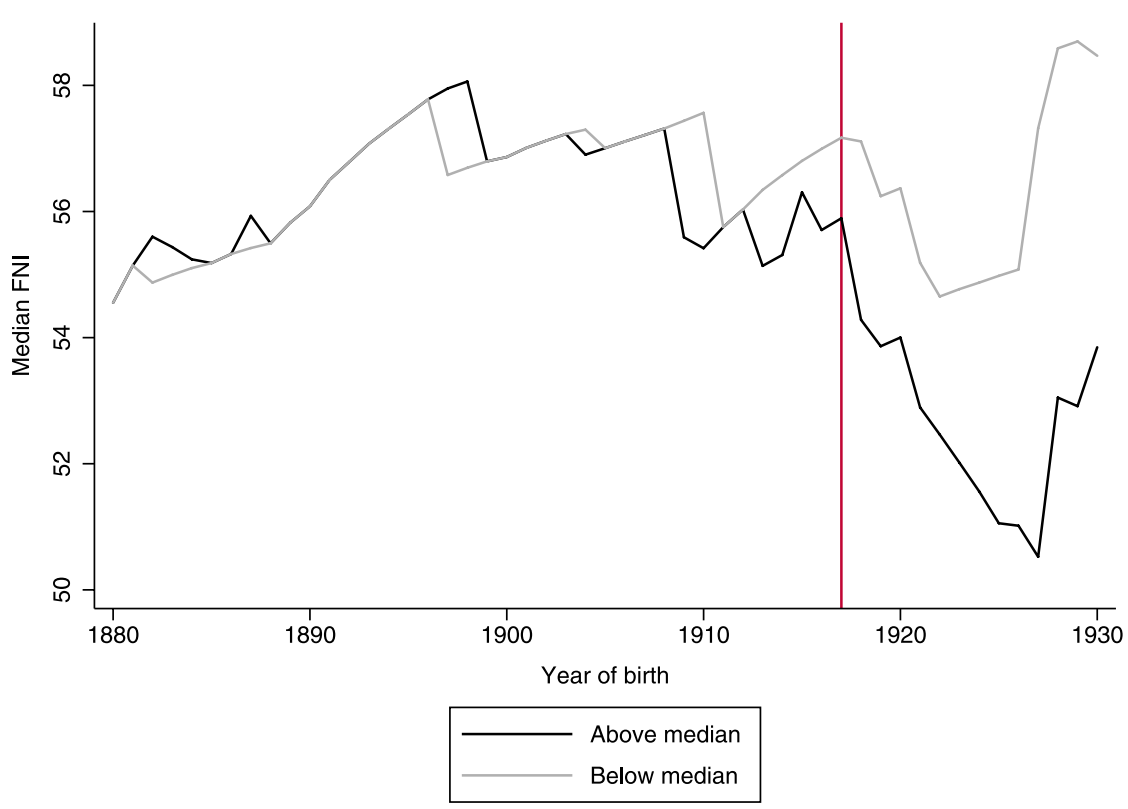

Notes: The dataset consists of second-generation German men. The black line corresponds to states with above-median change in support for Woodrow Wilson in the 1916 presidential election, and the gray line to states with below-median change in support. The vertical line is drawn at 1917.

patterns, the effect of voting patterns remains strong and significant.

Voting patterns in the 1916 presidential election could have been affected by more factors than foreign policy and anti-Germanism. I attempt to construct a more accurate proxy of native hostility against German immigrants, by compiling a list of incidents of public harassment from newspapers. I use ProQuest's Historical Newspapers archive to search for any such incidents reported after 1914. Figure 7 depicts the locations of the resulting list. Most cases of antiGerman violence were concentrated in the Midwest, particularly in the state of Illinois, where the largest communities of German immigrants were located. I compute the number of incidents per thousand residents by state and assign this measure to an individual's state of birth.

Panel B of Table 6 performs the same difference-indifferences analysis as before, using this new measure of discrimination. A higher incidence of public hostility is associated with a decrease in the FNI of German Americans born after 1917, and the effect is largely unchanged by the inclusion of interactions of 1910 statelevel controls and birth cohorts or of linear state trends. Coefficient estimates in Panel B of Table 6 imply that the average state that registered violent incidents against Germans saw an additional drop in the FNI of 1.79-2.13 index points compared to a state without reported incidents.

Overall, though one should be cautious with a causal interpretation of these state-level results, due to the potential endogeneity of anti-Germanism at the state level, the findings are nevertheless indicative of the same pattern: Germans reacted to either measure of discrimination and hostility by signaling assimilation through the choice of less distinctive names for their children after 1917.

\section{DISCUSSION}

How informative is the case of German Americans for the dynamics of discrimination and assimilation today? Anti-Germanism during World War I is best described by a preference-based model of discrimination, like the canonical approach in Becker (1957). While statistical discrimination (Arrow 1973; Coate and Loury 1993; Phelps 1972), which is motivated by a lack of information on certain groups' characteristics and reduces the return of their investment in skill acquisition, might be an important driver of immigrants' low integration today, there is also sufficient evidence that antiimmigrant sentiment is motivated mostly by cultural and not economic concerns (Hainmueller and Hopkins 2014; Sniderman, Hagendoorn, and Prior 2004). If taste-based factors motivate native behavior and if immigrants have the option of hiding their identifying ethnic or religious characteristics to fit in, then evidence from the German American case indicates that they will do so.

More broadly, most formal theories of discrimination do not allow for an assimilation choice for members of the discriminated group. One exception is Eguia (2017), who models discrimination as a rational screening 
TABLE 6. State-Level anti-German Sentiment and Naming Patterns

\begin{tabular}{|c|c|c|c|c|c|}
\hline \multirow[b]{3}{*}{ Dep. variable: } & \multicolumn{5}{|c|}{ FNI (Mean: 57.278) } \\
\hline & \multicolumn{5}{|c|}{ Panel A: State-level support for Woodrow Wilson } \\
\hline & {$[1]$} & [2] & [3] & [4] & [5] \\
\hline Wilson & $\begin{array}{l}-3.339 \\
(2.459)\end{array}$ & $\begin{array}{l}-1.947 \\
(2.738)\end{array}$ & & & \\
\hline Wilson $\times$ born 1917 or later & $\begin{array}{l}-9.970 \\
(7.019)\end{array}$ & $\begin{array}{c}-16.63^{\star \star *} \\
(4.802)\end{array}$ & $\begin{array}{c}-15.62^{\star \star \star} \\
(4.792)\end{array}$ & $\begin{array}{c}-16.41^{\star \star \star} \\
(4.515)\end{array}$ & $\begin{array}{c}-12.62^{* \star *} \\
(3.740)\end{array}$ \\
\hline \multirow[t]{2}{*}{$\begin{array}{l}\text { Observations } \\
R \text {-squared }\end{array}$} & $\begin{array}{c}1,572,997 \\
0.0179\end{array}$ & $\begin{array}{c}1,572,997 \\
0.0205\end{array}$ & $\begin{array}{c}1,572,997 \\
0.0242\end{array}$ & $\begin{array}{c}1,572,997 \\
0.0244\end{array}$ & $\begin{array}{c}1,572,997 \\
0.00702\end{array}$ \\
\hline & \multicolumn{5}{|c|}{ Panel B: State-level harassment incidents } \\
\hline Incidents per thousand & $\begin{array}{l}-66.65 \\
(135.1)\end{array}$ & $\begin{array}{l}-148.5 \\
(121.0)\end{array}$ & & & \\
\hline Incidents per thousand $\times$ born 1917 or later & $\begin{array}{l}-801.0^{\star} \\
(462.5)\end{array}$ & $\begin{array}{l}-716.1^{*} \\
(412.3)\end{array}$ & $\begin{array}{l}-673.4 \\
(427.1)\end{array}$ & $\begin{array}{c}-754.0^{\star} \\
(416.7)\end{array}$ & $\begin{array}{c}-754.0^{\star} \\
(416.7)\end{array}$ \\
\hline $\begin{array}{l}\text { Observations } \\
R \text {-squared }\end{array}$ & $\begin{array}{c}1,575,617 \\
0.0174\end{array}$ & $\begin{array}{c}1,575,617 \\
0.0197\end{array}$ & $\begin{array}{c}1,575,617 \\
0.0237\end{array}$ & $\begin{array}{c}1,575,295 \\
0.0239\end{array}$ & $\begin{array}{c}1,575,295 \\
0.00199\end{array}$ \\
\hline State FE & $\mathrm{N}$ & $\mathrm{N}$ & Y & Y & $\mathrm{Y}$ \\
\hline Year of birth FE $\times 1910$ German share & $\mathrm{N}$ & $\mathrm{Y}$ & Y & $\mathrm{Y}$ & $\mathrm{Y}$ \\
\hline Year of birth FE $\times 1910 \mathrm{FNI}$ & $\mathrm{N}$ & $\mathrm{N}$ & $\mathrm{N}$ & $\mathrm{Y}$ & Y \\
\hline Linear state trends & $\mathrm{N}$ & $\mathrm{N}$ & $\mathrm{N}$ & $\mathrm{N}$ & $\mathrm{Y}$ \\
\hline \multicolumn{6}{|c|}{$\begin{array}{l}\text { Notes: The dataset consists of all men born in the US } 1880-1930 \text { to a German-born father. All columns include birth year fixed effects. } \\
\text { Wilson is a measure of increase in a state's support for Woodrow Wilson between the presidential elections of } 1912 \text { and } 1916 \text {. Incidents } \\
\text { per thousand is the number of reported harassment incidents against Germans per thousand residents in the state during WWI. } \\
1910 \text { German share is the share of first-and second-generation Germans in the total population of the state in } 1910.1910 \text { FNI is the average } \\
\text { FNI of second-generation Germans born in the state before } 1914 \text {. The dependent variable in column (5) is the residual from a regression of } \\
\text { the FNI on linear state-specific trends fitted to the pre-war period. Standard errors are clustered at the state-of-birth level. Significance levels: }\end{array}$} \\
\hline
\end{tabular}

\section{FIGURE 7. Harassment Incidents Against Germans}

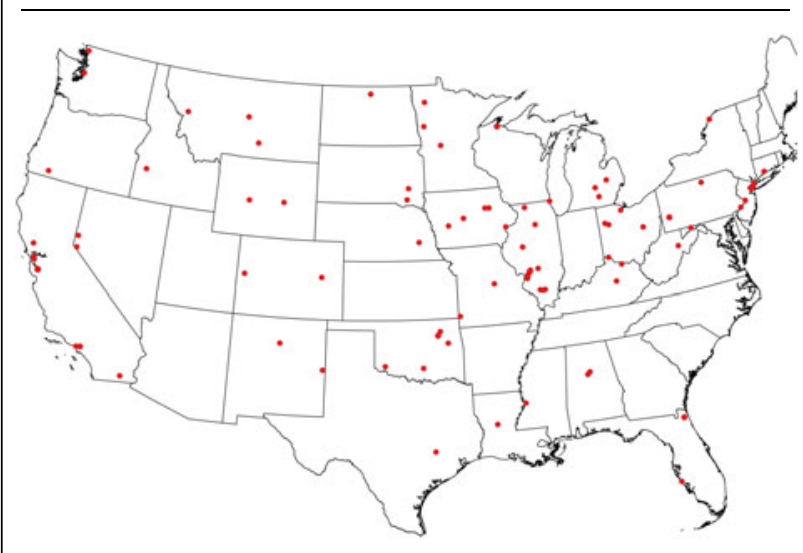

Notes: The figure depicts towns where at least one incident of public harassment against Germans took place during World War I, as reported in the press. Source: ProQuest Historical Newspapers.

strategy, and shows that such a filtering mechanism is successful in allowing only the highest skilled individuals to become members of the majority or dominant group. This model, however, does not account for any taste-based discrimination mechanism. Fearon (2013) models social mimicry, or the decision of agents to pass as members of another group, when that group has a technology for detecting mimics. The model predicts that passing rates will be decreasing in the quality of the target group's detection technology. To the extent that German Americans were physically and culturally close to Anglo-Saxons, the cost involved for natives who wanted to detect potential infiltrators or spies would have been high enough to allow for the high rates of assimilation that we observe empirically. This fact also potentially delineates the differences of the German American case from, for example, the case of Muslims in the West, which shares many similar features otherwise. The Germans' lower physical and cultural distance from the native average implied lower assimilation costs - e.g., name changes were much easier given existing similarities between German and American names-or, conversely, a higher return to any given assimilation effort.

The social psychology literature on perceptions of discrimination makes a distinction between personal 
and group-level discrimination (Fuegen and Biernat 2000; Taylor et al. 1990). The former is actual targeting of the individual (though still on the basis of group-level characteristics), while the latter is discrimination only against the group an individual belongs to. Effects of the two types of discrimination on political engagement differ. Schildkraut (2005) finds that personal discrimination is more likely to lead to alienation and political disengagement, though its effects can be moderated by minority group identification. ${ }^{10}$ The current study cannot distinguish between personal and group-level discrimination. In the absence of measures of individual exposure to discrimination or self-reported perceptions of discrimination, it is not clear whether Germans who filed for naturalization or changed their own and their children's names were responding to individual or group-level targeting.

Another distinction in types of discrimination and their effects comes from Oskooii (2016), who speaks of political and societal discrimination. He associates the first type with increased political activism, and the second one with disengagement. The results of the current study indicate that societal discrimination is also likely to increase formal political participation, at least in the form of naturalization, if that action can be perceived as a signal of patriotism and thus as likely to reduce harassment.

A distinction that seems more relevant in explaining why assimilation was a likely response to hostility for Germans in the US is the one between conditional and unconditional harassment. Bisin et al. (2011) make this distinction in a formal model of assimilation and oppositional identity, and define conditional harassment as discrimination dependent on the non-assimilated behavior of minorities. There is much evidence that harassment toward the German group was specifically intended to elicit signals of loyalty. Germans were more likely to be targeted for tarring and feathering or verbal abuse if they made unpatriotic statements in support of Germany or if they refused to buy liberty bonds. Minority groups are more likely to assimilate in response to conditional discrimination, exactly because it gives them more of an incentive to do so. If taste-based discrimination is not responsive to signals from the part of the minority, then there is no reason to undertake costly assimilation actions.

At this point it is worth noting that assimilation in terms of observable choices need not reflect the true preferences or identity of individuals. Greif and Tadelis (2010) construct a model of "crypto-morality," in which behavior is decoupled from people's true moral feelings. In the model, parents may adopt external behaviors that are compatible with an authority's moral demands, but continue to hold their own beliefs in private and transmit them to their offspring. This theory can account for the persistence of persecuted political and religious identities. There are indications that also in the case of German Americans, rapid assimilation in

\footnotetext{
${ }^{10}$ Not all studies reach the same conclusion. DeSipio (2002) finds that personal discrimination is more likely to increase political activism in a sample of Latinos, though he considers this result counterintuitive.
}

terms of observable characteristics may have gone hand in hand with the persistence of ethnic identity and preferences. Predominantly German American areas registered heavy opposition to Franklin D. Roosevelt's re-election in 1936 and 1940, largely reacting to his foreign policy and the prospect of a new war against Germany (Luebke 1974). While this may have simply been reflective of a desire to avoid a new wave of ethnic discrimination, it also indicates that, assimilation notwithstanding, German Americans continued acting as a distinct unified block in terms of their political behavior. Fouka (2018) finds that the second generation of German Americans who were exposed to German language bans while at school were more likely to marry other ethnic Germans, choose more German-sounding names for their children and were less likely to volunteer in the US army in World War II. The spatial patterns of this reaction suggest that private parental and community efforts to transmit the German identity were strengthened in response to the ban on ethnic schooling.

Nonetheless, independently of whether the observed behavior of Germans during World War I reflected a real identity change or only had signaling value, their actions almost certainly had real effects in the long-run. An increase in rates of citizenship constituted the first, formal, step for later political engagement through voting. Naming decisions may have also been consequential. Literature on the effects of characteristic minority names suggests that second-generation Germans with more American-sounding names would have been more integrated in terms of socioeconomic outcomes (Biavaschi, Giulietti, and Siddique 2017; Oreopoulos 2011). Thus, even if the actions of the first generation were purely formal responses to increased incentives to hide their true identity, they contributed to the long-run incorporation of the German immigrant minority into broader US society.

\section{CONCLUSION}

I examine the responses of immigrants to taste-based discrimination using the case of German Americans in the early twentieth century US. World War I was an exogenous shock to natives' attitudes, and during the war, many Germans suffered widespread harassment. I show that the war coincides temporally with a large and persistent drop in the ethnic distinctiveness of names of children born in the US to German parents, and an increase in name changes and in the number of petitions for naturalization filed by Germans compared to other immigrant groups. This is not only a result of less assimilated Germans leaving the country during and after WWI. For households still present in the US after the war, children born after 1917 have less German names than those born in pre-war years. Name assimilation was higher in states that, during the 1916 presidential election, registered higher support for Woodrow Wilson, the presidential candidate who targeted hyphenated identities and demanded signs of loyalty from the German American community, and in 
states where more incidents of harassment against Germans took place during the war.

The pattern of intensified assimilation efforts was not uniform. Additional analyses reported in Section $E$ of the Online Appendix show that parents who chose less German-sounding names for their children had on average lived longer in the US and were more likely to be naturalized US citizens. Endogamous German couples were less likely to assimilate than mixed ones and much of the increase in both declarations and petitions for naturalization after 1917 came from German nationals who were older and had been in the country longer at the time of application. This indicates that assimilation responses are larger for groups that are already better integrated into US society. These groups have lower costs of assimilation effort and also face potentially larger losses from discrimination, because they are more invested in the host country.

These findings have implications for an understanding of minority behavior and the dynamics of discrimination. While observed integration patterns such as political representation, intermarriage rates and labor market outcomes are equilibrium outcomes that depend both on immigrants' decisions and on the behavior of natives, both names and petitions for naturalization reflect purely immigrant choices. The results indicate that the association between discrimination and low integration observed in equilibrium would be even stronger in the absence of immigrant assimilation efforts. At the same time, the heterogeneity of responses among the immigrant population suggests that the costs of assimilation effort are important drivers of immigrant decisions.

\section{SUPPLEMENTARY MATERIAL}

To view supplementary material for this article, please visit https://doi.org/10.1017/S0003055419000017.

Replication materials can be found on Dataverse at: https://doi.org/10.7910/DVN/DHZBAB.

\section{REFERENCES}

Abramitzky, Ran, Leah Platt Boustan, and Katherine Eriksson. 2014. "A Nation of Immigrants: Assimilation and Economic Outcomes in the Age of Mass Migration." Journal of Political Economy 122 (3): 467-717.

Abramitzky, Ran, Leah Platt Boustan, and Katherine Eriksson. 2016. "Cultural Assimilation During the Two Ages of Mass Migration." Working Paper, Stanford University. https://people.stanford.edu/ ranabr/sites/default/files/cultural_assimilation.pdf.

Adida, Claire L., David D. Laitin, and Marie-Anne Valfort. 2014. "Muslims in France: Identifying a Discriminatory Equilibrium." Journal of Population Economics 27 (4): 1039-86.

Algan, Yann, Thierry Mayer, and Mathias Thoenig. 2013. The Economic Incentives of Cultural Transmission: Spatial Evidence from Naming Patterns across France. CEPR Discussion Papers 9416. https://ssrn.com/abstract $=2247276$

Arrow, Kenneth J. 1973. "The Theory of Discrimination.” In Discrimination in Labor Markets, eds. Orley Ashenfelter and Albert Rees. Princeton, NJ: Princeton University Press, 3-33.
Bandiera, Oriana, Imran Rasul, and Martina Viarengo. 2013. "The Making of Modern America: Migratory Flows in the Age of Mass Migration." Journal of Development Economics 102: 23-47.

Becker, Gary S. 1957. The Economics of Discrimination. Chicago: University of Chicago Press.

Bertrand, Marianne, and Sendhil Mullainathan. 2004. "Are Emily and Greg More Employable Than Lakisha and Jamal? A Field Experiment on Labor Market Discrimination." The American Economic Review 94 (4): 991-1013.

Biavaschi, Costanza, Corrado Giulietti, and Zahra Siddique. 2017. "The Economic Pay-Off of Name Americanization." Journal of Labor Economics 35 (4): 1089-116.

Bisin, Alberto, Eleonora Patacchini, Thierry Verdier, and Yves Zenou. 2011. "Formation and Persistence of Oppositional Identities." European Economic Review 55 (8): 1046-71.

Brader, Ted, Nicholas A Valentino, and Elizabeth Suhay. 2008. "What Triggers Public Opposition to Immigration? Anxiety, Group Cues, and Immigration Threat." American Journal of Political Science 52 (4): 959-78.

Butler, Daniel M., and David E. Broockman. 2011. "Do Politicians Racially Discriminate against Constituents? A Field Experiment on State Legislators." American Journal of Political Science 55 (3): 463-77.

Chandra, Kanchan. 2001. "Cumulative Findings in the Study of Ethnic Politics." APSA-CP 12 (1): 7-11.

Cho, Wendy K. Tam, James G.Gimpel, and Tony Wu. 2006. "Clarifying the Role of SES in Political Participation: Policy Threat and Arab American Mobilization." The Journal of Politics 68 (4): 977-91.

Coate, Steven, and Glenn Loury. 1993. "Will Affirmative-Action Policies Eliminate Negative Stereotypes?" The American Economic Review 83 (5): 1220-40.

Conzen, Cathleen Neils. 1980. "Germans." In Harvard Encyclopedia of American Ethnic Groups, eds. Stephan Thernstrom, Ann Orlov, and Oscar Handlin. Cambridge, Massachusetts: Belknap Press of Harvard University Press, 423.

Cook, Lisa D., Trevon D. Logan, and John M. Parman. 2014. "Distinctively Black Names in the American Past." Explorations in Economic History 53: 64-82.

Dancygier, Rafaela M., Karl-Oskar Lindgren, Sven Oskarsson, and Kåre Vernby. 2015. "Why Are Immigrants Underrepresented in Politics? Evidence from Sweden." American Political Science Review 109 (4): 703-24.

Dargent, Claude. 2003. "Les musulmans déclarés en France: affirmation religieuse, subordination sociale et progressisme politique." Les cahiers du Cevipof 34: 2-42.

Dávila, Alberto, and Marie Mora. 2005. "Changes in the Earnings of Arab Men in the US between 2000 and 2002." Journal of Population Economics 18 (4): 587-601.

DeSipio, Louis. 2002. Immigrant Organizing, Civic Outcomes: Civic Engagement, Political Activity, National Attachment, and Identity in Latino Immigrant Communities. Paper No. 02-08. Center for the Study of Democracy. http://www.u.arizona.edu/ jag/POL596A/ desipioimmig.pdf.

Dinas, Elias, Konstantinos Matakos, Dimitrios Xefteris, and Dominik Hangartner. 2019. "Waking up the Golden Dawn: Does Exposure to the Refugee Crisis Increase Support for Extreme-Right Parties?" Political Analysis 1-11. doi:10.1017/pan.2018.48.

Duguet, Emmanuel, Noam Leandri, Yannick L'Horty, and Pascale Petit. 2010. "Are Young French Jobseekers of Ethnic Immigrant Origin Discriminated against? A Controlled Experiment in the Paris Area." Annals of Economics and Statistics 99 (100): 187-215.

Eguia, Jon X. 2017. "Discrimination and Assimilation at School." Journal of Public Economics 156: 48-58.

Fearon, James D. 2013. "Strategic Dynamics of Social Mimicry." Working Paper, Stanford University. https://web.stanford.edu/ group/fearon-research/cgi-bin/wordpress/wp-content/uploads/ 2013/10/socialmimicry2.pdf.

Fearon, James D., and David D. Laitin. 1996. "Explaining Interethnic Cooperation." American Political Science Review 90 (4): 715-35.

Fix, Michael, and Margery Austin Turner. 1998. A National Report Card on Discrimination in America: The Role of Testing. Washington, DC: Urban Institute Press.

Fouka, Vasiliki. 2018. Backlash: The Unintended Eeffects of Language Prohibition in US Schools after World War I. Working 
Paper, Stanford University. https://people.stanford.edu/vfouka/ sites/default/files/backlash2018_0.pdf.

Fryer, Roland G., and Steven D. Levitt. 2004. "The Causes and Consequences of Distinctively Black Names." Quarterly Journal of Economics 119 (3): 767-805.

Fuegen, Kathleen, and Monica Biernat. 2000. "Defining Discrimination in the Personal/Group Discrimination Discrepancy." Sex Roles 43 (5-6): 285-310.

Glidden, William B. 1973. "Internment Camps in America, 1917-1920." Military Affairs 37 (4): 137-41.

Goldin, Claudia, and Cecilia Rouse. 2000. "Orchestrating Impartiality: The Impact of "Blind" Auditions on Female Musicians." The American Economic Review 90 (4): 715-41.

Gómez, Ángel, J. Francisco Morales, Sonia Hart, Alexandra Vásquez, and William B. Swann Jr. 2011. "Rejected and Excluded Forevermore, but Even More Devoted: Irrevocable Ostracism Intensifies Loyalty to the Group Among Identity-Fused Persons." Personality and Social Psychology Bulletin 37 (12): 1574-86.

Gould, Eric D., and Esteban F. Klor. 2016. "The Long-Run Effect of 9/11: Terrorism, Backlash, and the Assimilation of Muslim Immigrants in the West." The Economic Journal 126 (597): 2064-114.

Greif, Avner, and Steven Tadelis. 2010. "A Theory of Moral Persistence: Crypto-Morality and Political Legitimacy." Journal of Comparative Economics 38 (3): 229-44.

Haines, Michael R., and ICPSR. 2010. Historical, Demographic, Economic, and Social Data: The United States, 1790-2002 [Computer file]. ICPSR02896-v3. Ann Arbor, MI: Inter-university Consortium for Political/Social Research [distributor].

Hainmueller, Jens, and Dominik Hangartner. 2013. "Who Gets a Swiss Passport? A Natural Experiment in Immigrant Discrimination." American Political Science Review 107 (1): 159-87.

Hainmueller, Jens, Dominik Hangartner, and Giuseppe Pietrantuono. 2015. "Naturalization Fosters the Long-Term Political Integration of Immigrants." Proceedings of the National Academy of Sciences 112 (41): 12651-6.

Hainmueller, Jens, Dominik Hangartner, and Giuseppe Pietrantuono. 2017. "Catalyst or Crown: Does Naturalization Promote the LongTerm Social Integration of Immigrants?” American Political Science Review 111 (2): 256-76.

Hainmueller, Jens, and Daniel J. Hopkins. 2014. "Public Attitudes toward Immigration." Annual Review of Political Science 17: $225-49$.

Head, Keith, and Thierry Mayer. 2008. "Detection of Local Interactions from the Spatial Pattern of Names in France." Journal of Regional Science 48 (1): 67-95.

Higham, John. 1998. Strangers in the Land: Patterns of American Nativism, 1860-1925. New Brunswick: Rutgers University Press.

Jones-Correa, Michael. 2001. "Under Two Flags: Dual Nationality in Latin America and its Consequences for Naturalization in the United States." International Migration Review 35 (4): 997-1029.

Kazal, Russell. 2004. Becoming Old Stock: The Paradox of GermanAmerican Identity. Princeton, NJ: Princeton University Press.

Kuo, Alexander, Neil Malhotra, and Cecilia Hyunjung Mo. 2017. "Social Exclusion and Political Identity: The Case of Asian American Partisanship." The Journal of Politics 79 (1): 17-32.

Laitin, David D. 1986. Hegemony and Culture: Politics and Change Among the Yoruba. Chicago, IL: University of Chicago Press.

Laitin, David D. 1995. "Marginality: A Microperspective." Rationality and Society 7 (1): 31-57.

Laitin, David D. 1998. Identity in Formation: The Russian-Speaking Populations in the Near Abroad. Ithaca, NY: Cornell University Press.

Lieberson, Stanley. 2000. A Matter of Taste: How Names, Fashions, and Culture Change. New Haven: Yale University Press.

Luebke, Frederick C. 1974. Bonds of Loyalty: German-Americans and World War I. Urbana: Northern Illinois University Press.

Luebke, Frederick C. 1999. Germans in the New World: Essays in the History of Immigration. Urbana: University of Illinois Press.

Lyons-Padilla, Sarah, Michele J. Gelfand, Hedieh Mirahmadi, Mehreen Farooq, and Marieke van Egmond. 2015. "Belonging Nowhere: Marginalization \& Radicalization Risk Among Muslim Immigrants.” Behavioral Science \& Policy 1 (2): 1-12.

Manning, Alan, and Sanchari Roy. 2010. "Culture Clash or Culture Club? National Identity in Britain." The Economic Journal 120 (542): F72-F100.
Mill, Roy, and Luke C. D. Stein. 2016. "Race, Skin Color, and Economic Outcomes in Early Twentieth-Century America." Working Paper, Arizona State University. https://papers.ssrn.com/sol3/ papers.cfm?abstract_id $=2741797$.

Minnesota Population Center and Ancestry.com. 2013. IPUMS Restricted Complete Count Data: Version 1.0 [Machine-readable database]. Minneapolis: University of Minnesota.

Mitts, Tamar. 2019. "From Isolation to Radicalization: Anti-Muslim Hostility and Support for ISIS in the West." American Political Science Review 113 (1): 173-94. doi:10.1017/S0003055418000618.

Mohamed, Heather Silber. 2017. The New Americans? Immigration, Protest, and the Politics of Latino Identity. Lawrence, Kansas: University Press of Kansas.

Moser, Petra. 2012. "Taste-Based Discrimination. Evidence from a Shift in Ethnic Preferences after WWI." Explorations in Economic History 49 (2): 167-88.

Nagler, Jörg. 1993. "Enemy Aliens in the USA, 1914-1918." In Minorities in Wartime: National and Racial Groupings in Europe, North America and Australia during the Two World Wars, ed. Panikos Panayi. Oxford, Providence: Berg Publishers, 191-215.

Neeraj, Kaushal, Robert Kaestner, and Cordelia Reimers. 2005. "Labor Market Effects of September 11th on Arab and Muslim Residents of the United States." Journal of Population Economics 18 (4): 587-601.

Nix, Emily, and Nancy Qian. 2015. "The Fluidity of Race: "Passing” in the United States, 1880-1940." NBER Working Paper 20828. http:// www.nber.org/papers/w20828.

Oreopoulos, Philip. 2011. "Why Do Skilled Immigrants Struggle in the Labor Market? A Field Experiment with Thirteen Thousand Resumes." American Economic Journal: Economic Policy 3 (4): 148-71.

Oskooii, Kassra A. R. 2016. "How Discrimination Impacts Sociopolitical Behavior: A Multidimensional Perspective." Political Psychology 37 (5): 613-40.

Oskooii, Kassra A. R. 2018. "Perceived Discrimination and Political Behavior." British Journal of Political Science 1-26. doi:10.1017/ S0007123418000133.

Pantoja, Adrian D., Ricardo Ramirez, and Gary M. Segura. 2001. "Citizens by Choice, Voters by Necessity: Patterns in Political Mobilization by Naturalized Latinos." Political Research Quarterly 54 (4): 729-50.

Phelps, Edmund S. 1972. "The Statistical Theory of Racism and Sexism." The American Economic Review 62: 659-61.

Posner, Daniel N. 2005. Institutions and Ethnic Politics in Africa. Cambridge, UK: Cambridge University Press.

Ruggles, Steven, Katie Genadek, Ronald Goeken, Josiah Grover, and Matthew Sobek. 2010. Integrated Public Use Microdata Series: Version 5.0 [Machine-Readable Database]. Minneapolis: University of Minnesota.

Saperstein, Aliya, and Andrew M. Penner. 2012. "Racial Fluidity and Inequality in the United States." American Journal of Sociology 118 (3): 676-727.

Schildkraut, Deborah J. 2005. "The Rise and Fall of Political Engagement Among Latinos: The Role of Identity and Perceptions of Discrimination." Political Behavior 27 (3): 285-312.

Sidanius, Jim, Seymour Feshbach, Shana Levin, and Felicia Pratto. 1997. "The Interface between Ethnic and National Attachment: Ethnic Pluralism or Ethnic Dominance?" Public Opinion Quarterly 61 (1): 102-33.

Sides, John, and Jack Citrin. 2007. "European Opinion about Immigration: The Role of Identities, Interests and Information." British Journal of Political Science 37 (3): 477-504.

Sniderman, Paul M., Louk Hagendoorn, and Markus Prior. 2004. "Predisposing Factors and Situational Triggers: Exclusionary Reactions to Immigrant Minorities." American Political Science Review 98 (01): 35-49.

Sowell, Thomas. 1996. Migration and Cultures. New York: Basic Books.

Steinmayr, Andreas. 2018. "Contact Matters: Exposure to Refugees and Voting for the Far-Right." Working Paper, LMU Munich. https://docs.google.com/viewer? $\mathrm{a}=\mathrm{v} \&$ pid $=$ sites\&srcid $=\mathrm{ZGVmY}$ XVsdGRvbWFpbnxhbmRyZWFzc3RlaW5tYXlyfGd4OjcyYzAx MjA0ZlWRhODJmZGI.

Taylor, Donald M., Stephen C. Wright, Fathali M. Moghaddam, and Richard N. Lalonde. 1990. "The Personal/Group Discrimination Discrepancy: Perceiving My Group, but Not Myself, to Be a Target 
for Discrimination.” Personality and Social Psychology Bulletin 16 (2): 254-62.

Uhlaner, Carole Jean. 1991. "Political Participation and Discrimination: A Comparative Analysis of Asians, Blacks, and Latinos." In Political Participation and American Democracy, ed. William Crotty. New York: Greenwood Press, 139-70.
US Department of Labor, Bureau of Naturalization. 1913-1923. Annual Report of the Commissioner of Naturalization to the Secretary of Labor. Washington D.C.: US Department of Labor.

Williams, Kipling D., and Kristin L. Sommer. 1997. "Social Ostracism by Coworkers: Does Rejection Lead to Loafing or Compensation?" Personality and Social Psychology Bulletin 23 (7): 693-706. 